\title{
RENAL REABSORPTION OF CHLORIDE AND PHOSPHATE \\ IN NORMAL SUBJECTS AND IN PATIENTS WITH ESSENTIAL ARTERIAL HYPERTENSION ${ }^{1}$
}

\author{
By EDITH B. FARNSWORTH
}

(From the Department of Medicine, Northwestern University Medical School)

(Received for publication August 17, 1946)

The threshold theory of chloride excretion was formulated by Rehberg (1) in 1926. Chloride studies in recent years have included those of Dillon (2), Hare, Hare and Phillips (3), Shannon (4) and Wolf (5). Pitts in 1945 (6) considered chloride with reference to renal methods for the acidification of urine, and Wolf applied the law of exponential decay to his analysis of chloride disposal under varying infusion loads and at varying time intervals. $\mathrm{He}$ found certain "critical concentrations of infusion fluid and urine, at which neither solute nor water are retained from an infusion, relative to one another." This study is thus an extension of Rehberg's threshold studies, through the extremes of load, and confirms the impression of a "plasma concentration above which chloride is excreted relative to water, and below which chloride is retained relative to water." Wolf also finds a "distortion or departure from normal of the ratio of chloride to non-chloride space, induced by this load."

Our interest in chloride metabolism was stimulated by an observation made in the course of routine clearance studies done upon a group of patients suffering from essential arterial hypertension $(7,8)$. It was found that the clearance of chloride in such patients tended to parallel the urine output, whereas in normal subjects the chloride clearance remained within a certain range, regardless of the volume output. In a preliminary series, values of chloride clearance periods rose as high as $6.6 \mathrm{ml}$. per minute, with a urine output of $7.4 \mathrm{ml}$. per minute, while control subjects tended not to exceed values of 3.0 to $3.4 \mathrm{ml}$. per minute, even with a urinary flow of 11 to $12 \mathrm{ml}$. per minute. We then attempted to investigate the mechanism of this phenomenon and hence to arrive at an evaluation of its significance and implications.

\footnotetext{
1 Funds for this study were obtained through the Alice Cook Guild Memorial Fund for Medical Research, established by Kenneth G. Smith.
}

The technique of multiple clearance was chosen because it supplied us with the filtration rate, the effective renal blood flow, and, by calculation of the $U / P$ inulin, a helpful index to water reabsorption. It will be readily seen that the ratio of urine concentration to plasma concentration, or $U / P$ inulin, is serviceable in 2 important respects, namely, that the complete filtration of inulin through the glomerular membrane is thoroughly established, and the concentration in the filtrate is known to equal that in the plasma; and secondly, that it is inert in the tubules. The $U / P$ inulin can, therefore, be altered only by a change in the volume of the solvent. Such a change would, in the light of present concepts of renal physiology, be accomplished by reabsorption of water by the tubules. Thus, a U/P inulin of 100 indicates that the urine is 100 times as concentrated as the plasma, and that the corresponding volume of water has been reabsorbed from the glomerular filtrate. Likewise, if the $U / P$ inulin is 1 , then no water has been reabsorbed; the urine concentration equals the plasma concentration, and the urine flow is equal to the filtration rate.

Adopting, then, the inulin ratios as a measure of tubular reabsorption of water, and the range of those ratios as the pattern of renal behavior toward a substance which has no function in the body, the pattern for a threshold substance might now be predicted. Taking again, for example, a $\mathrm{U} / \mathrm{P}$ inulin of 100 , at which ratio 99 parts of water would have been reabsorbed, a threshold substance would show a smaller ratio, since the urine concentration, or the numerator, would have been modified not only by the 99 parts of water removed, but by the reabsorption to some degree of the solute. How much less the $U / P$ ratio would be than that of inulin would depend upon the amount of the substance reabsorbed. Nonthreshold substances might be expected to be less extensively reabsorbed than would threshold sub- 
stances, but the strongest evidence of the character of the absorptive mechanism could be seen in the ability of the $U / P$ ratios to fall below 1 , since that situation could exist only if the tubules were able to reabsorb abundantly even at low $U / P$ inulin ratios. Thus, if the $U / P$ ratio of a given substance could sink below 1 , it would be exceedingly difficult to wash that substance out of the body. If, in addition, such a substance could be shown to be reclaimed in defiance of decreasing tubular resorption of water, to the point where the $U / P$ inulin is 1 , and no water whatever were reabsorbed, then a U/P of 1 would complete the reabsorption gradient of a perfect threshold substance. Such a gradient would imply an exceedingly delicate and effective guardianship of an indispensable metabolite.

If, on the other hand, another substance were shown to have, at all $U / P$ inulin ratios, a somewhat higher $U / P$ ratio than did the threshold substance, but one still greatly lower than that of the totally inert polysaccharide, it would be deduced that a certain quantity had been reabsorbed from the glomerular filtrate, that quantity being less than that of the threshold substance. If this second substance were similarly calculated in terms of $U / P$ and plotted against the $U / P$ inulin, a figure of 1 at $U / P$ inulin equals 1 would indicate that a urine unmodified toward inulin would also be unmodified toward such a non-threshold substance: The tubular cells would have reabsorbed neither water nor the metabolite in question which would, under these conditions, be as inert as inulin. If this were the case, it would be possible to wash such a substance out of the body, and the reabsorption gradient would be a graphic representation of a non-threshold substance.

In addition to clearance determinations of inulin and diodrast, chloride was chosen for analysis as a threshold substance, and phosphate as a probable non-threshold substance.

\section{METHODS}

Subjects were selected who, although complaining of "essential hypertension," gave no evidence of primary cardiac or renal disease. They varied in age from 19 to 60 years. The control group was drawn from other services in the hospital, and all subjects were found to be free from cardio-vascular or renal disease before they were included in the series.

The study was divided into 2 parts: the first being a consideration of 2 random groups, having only the qualifications just described, the second being a protracted study of 2 individuals of the same sex and of comparable age, one of whom had essential hypertension of long duration, the other of whom had no demonstrable pathology of the heart, blood vessels or kidneys.

Concomitant clearance periods of inulin, diodrast, chloride, and phosphate were run on all subjects. All had the same type of diet, and were similarly hydrated prior to the tests which were performed in the fasting state. The clearance periods varied from 15 to 30 minutes in length, and the blood specimens were drawn in the first and third periods. The urine specimens were collected by catheter and the bladder was washed with sterile water, the washings being added to the collections. Blood samples for serum chlorides were drawn under oil, and analyzed by the method of Sendroy (9). Inulin determinations were performed by the method of Corcoran and Page (10).

Since the volume of infusion was small, and varied but slightly from case to case, the "load," as defined by Wolf, was negligible, and the subjects were regarded as in chloride balance. Since, too, the present method has had but little application, the behavior of the control group seemed to us worthy of particular analysis.

\section{RESULTS}

Repeated determinations performed on a normal subject indicated that $\mathrm{U} / \mathrm{P}$ chloride is directly related to $U / P$ inulin, and hence that the 2 values plotted against each other form a straight line. The same is true of a group of normal subjects, although the scatter was greater (Figure 1).

In the normal individual, as the $U / P$ inulin decreased and the regression line approached a U/P inulin of 1 , the $U / P$ chloride fell below 1 and approached zero (Figure 2).

Phosphate values on the same individual, similarly plotted, also fell in a straight line, and the calculated regression line ran exactly through the point at which $U / P$ inulin and $U / P$ phosphate were 1 (Figure 3 ).

Comparing now the behavior of hypertensive subjects with the normal curves, Figure 1 shows that with rare overlapping determinations, the chloride ratio was higher at all inulin ratios in the experimental group than in the control group. Figure 2 demonstrates the same phenomenon in a single hypertensive subject when studied at varying rates of urine flow.

\section{DISCUSSION}

Returning to the threshold concept, let us examine the normal chloride curves in Figures 1 


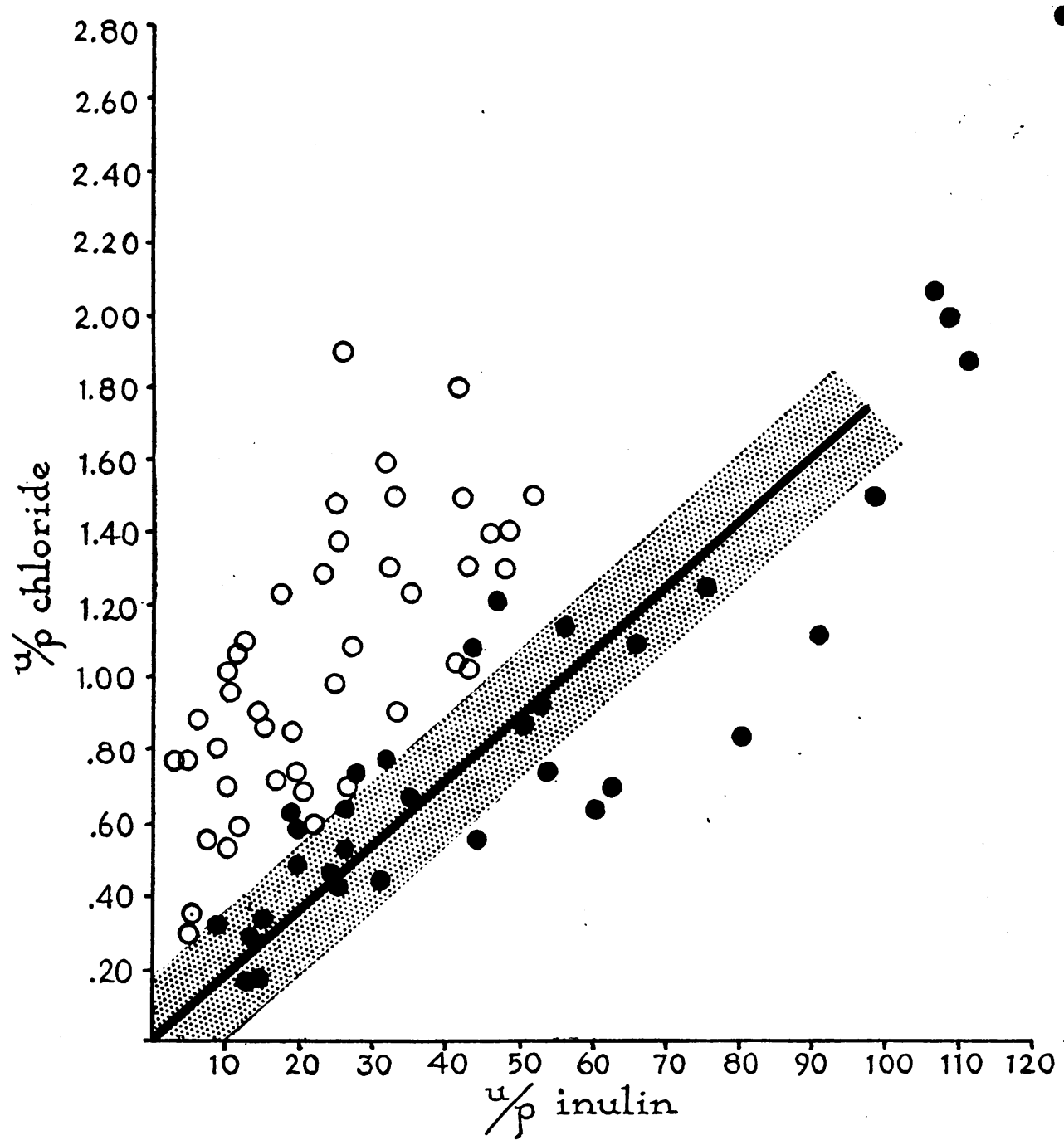

Fig. 1. U/P Chloride in Terms of U/P InUlin

Black symbols represent normal subjects; white symbols represent subjects with essential arterial hypertension. The coefficient of linear correlation for the normal group is : $r=0.964$ with a probable error of \pm 0.0082 .

and 2 to see how these data may be brought into conformity with the threshold theory. In no instance was the plasma chloride elevated or depressed beyond normal limits; hence it may be argued that the theory may not be applied. In raising the urinary output by water diuresis, however, and lowering the U/P inulin, the hypochloremic state may be thought of as instantly recurring and being compensated, in the only fashion by which a decreased plasma chloride could occur without affecting other physiological factors to such an extent as to obscure the renal dynamics toward chloride alone. At all outputs, then, the ratio of $U / P$ chloride to $U / P$ inulin was found to describe a constant proportion. Extrapolating for figures below those which are physiologically demonstrable, the regression line is seen to pass through $\mathrm{U} / \mathrm{P}$ chloride ratios of decreasing fractions to a theoretical zero at $\mathrm{U} / \mathrm{P}$ inulin unity. At this hypothetical end point the entire volume of glomerular filtrate would pass unmodified through the tubules, while all the chloride would be extracted and restored to the circulating plasma. Such a gradient appears to represent the pattern 
of conservation practiced by the normal human subject in whom a water load is constantly producing a diminished plasma chloride concentration.

It is, perhaps, not out of order to add that one patient under treatment for Addison's disease was studied by the same method. The plasma chloride in this individual was $488 \mathrm{mgm}$. per cent. The ratio of $\mathrm{U} / \mathrm{P}$ chloride to $\mathrm{U} / \mathrm{P}$ inulin was found to be somewhat above the zone of estimate for our normal group. The chloride clearance was well within the normal range.

The finding of a constant proportion between reabsorption of chloride and that of water implies a very delicate balance between the inverse activities of proximal and distal tubules, since chloride reabsorption is known to be carried on in the

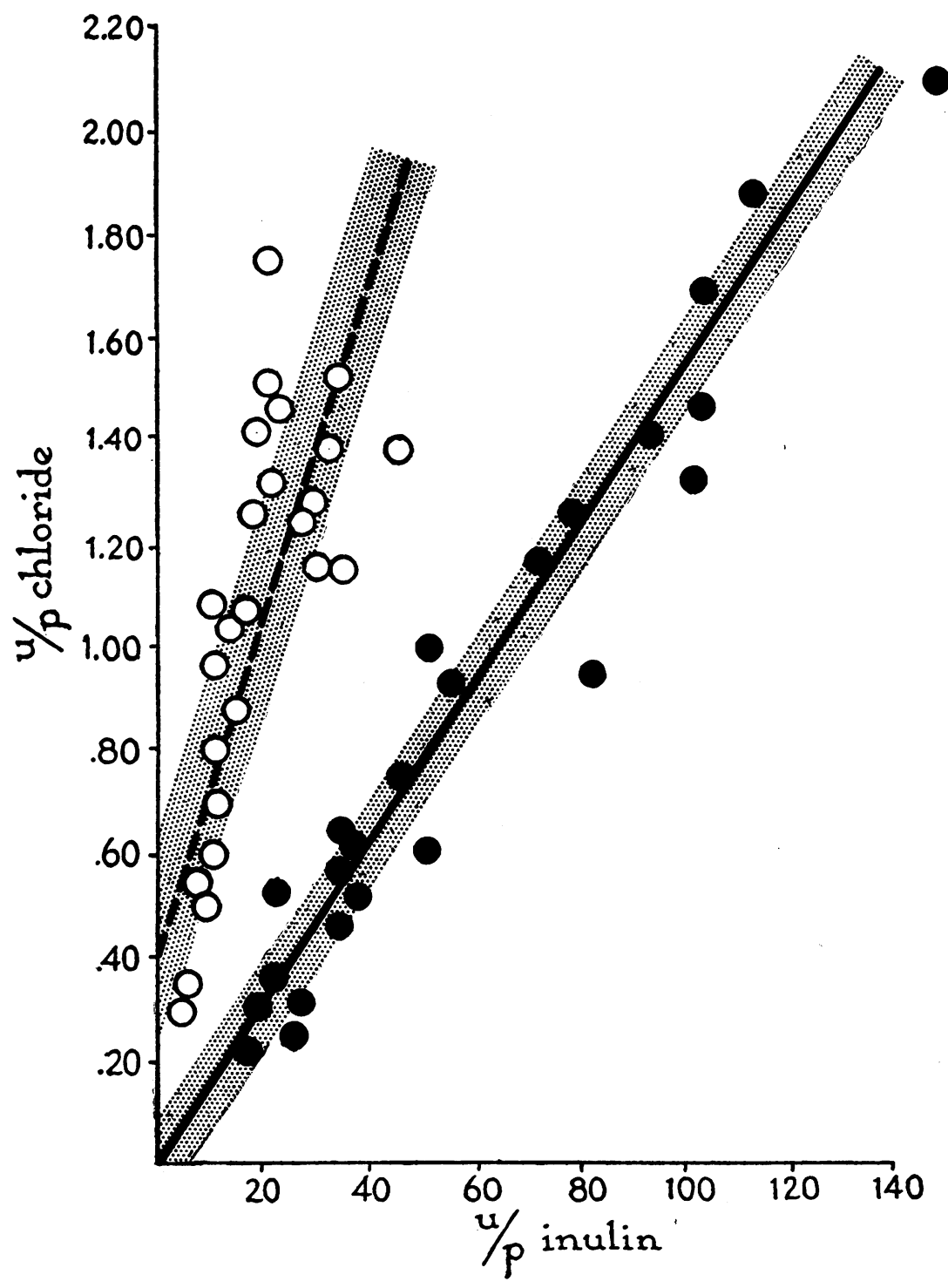

Fig. 2. U/P ChLoride in Terms of U/P InUlin

Black symbols represent clearance periods obtained from a normal subject; white symbols represent clearance periods from a patient with essential arterial hypertension. The coefficient of linear correlation for the normal subject is $.989 \pm .0045$ with a standard error of estimate of .09 . The coefficient of linear correlation for the hypertensive patient is $.894 \pm .0261$ with a standard error of estimate of .18 . 


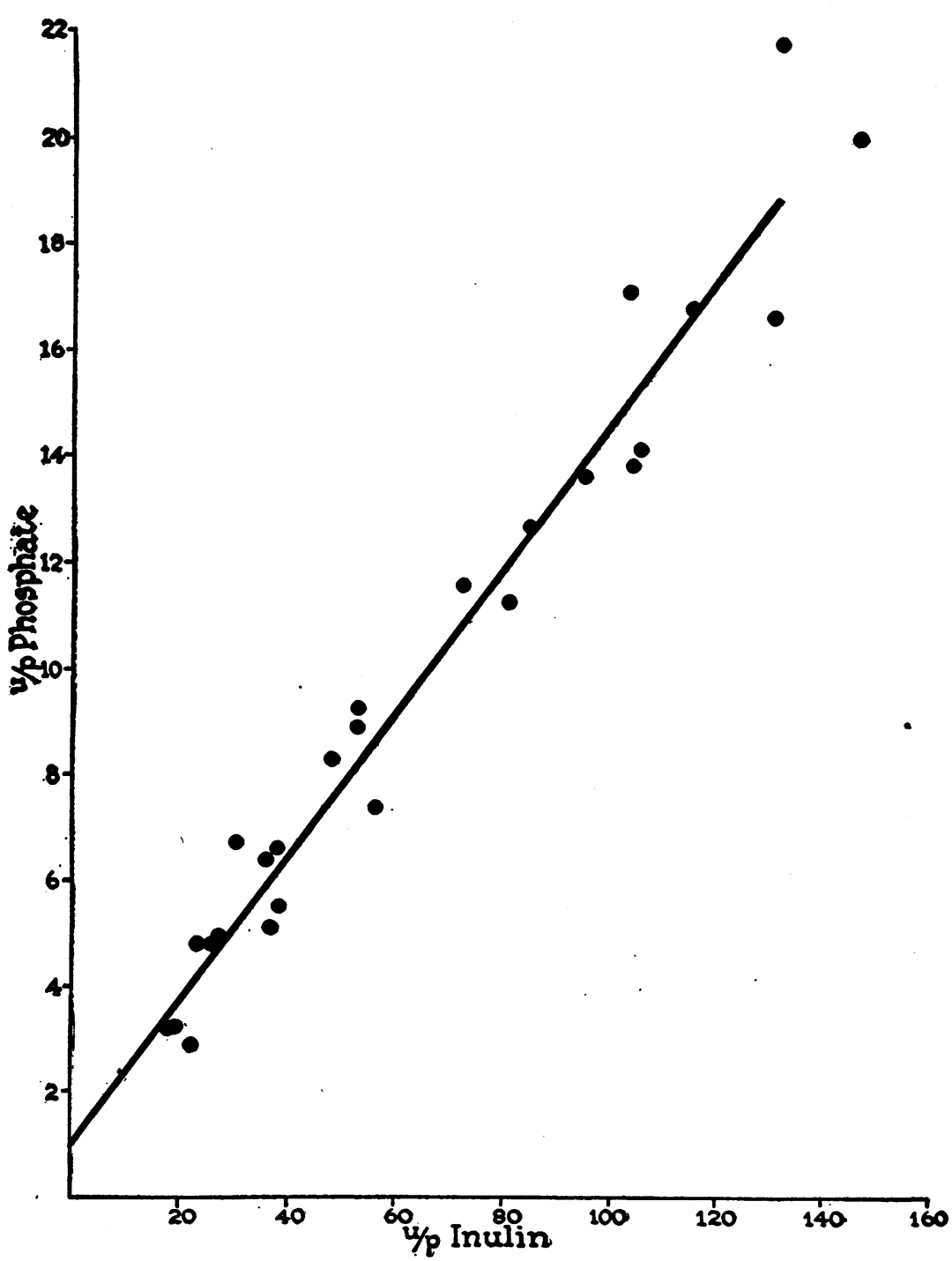

Fig. 3. U/P Phosphate in Terms of U/P InULin

Symbols represent clearance periods obtained from the same normal subject.

proximal convolutions, while water is largely reabsorbed in the distal portions. Thus, while the proximal tubules are reabsorbing more chloride, the distal tubules are reabsorbing less water, the resultant of these operations remaining constant. The numerical ratio of this constant proportion evidently varies somewhat in different individuals, since the scatter is greater in the group study than in the individual; but even in the group the resultant regression line extrapolates to $U / P$ inulin equals zero (or 1.0) and the ratio is hence always the same.
In contrast to the chloride situation, the $U / P$ phosphate values (Figure 3) were found to run higher than the chloride ratios, although always lower than those of inulin itself. Here again, good correlation was found with $U / P$ inulin, and a straight line curve resulted. Phosphate is, therefore, seen to be reabsorbed during its passage in solution through the tubules, but in diminishing proportion until, at the theoretical end point of $\mathrm{U} / \mathrm{P}$ inulin unity, the $\mathrm{U} / \mathrm{P}$ phosphate would also be unity, and the tubular cells would reabsorb neither water nor phosphate. Here again, is a 
gradient, a non-threshold graph, similar to that of chloride, but resulting in opposite physiological accomplishment.

It is noteworthy that the $U / P$ inulin values in the hypertensives are limited to a comparatively narrow range, extending from 4.8 to around 50 , while normal subjects, under identical routine preparation, showed inulin ratios as high as 200 . It is highly probable that this failure to reabsorb water is simply an expression of hyposthenuria corresponding to degeneration of the distal tubules. If such be the case, this limitation of the $\mathrm{U} / \mathrm{P}$ inulin range might well serve as a practicable clinical test, possibly employed with the single injection mẹthod.

Turning now to the data as they pertain to the hypertensive patients, Tables I and II show the clearance of chloride running materially higher in

TABLE I

Data obtained from a group of patients with essential arterial hypertension

\begin{tabular}{|c|c|c|c|c|c|c|c|c|}
\hline & B.P. & ml. per min. & $\mathrm{C}_{\text {In. }}$ & $\mathrm{C}_{\text {Diod. }}$ & $\mathrm{C}_{\text {Chlor. }}$ & FF & U/P Chlor. & U/P In. \\
\hline \multirow[t]{4}{*}{ C. V. } & $210 / 140$ & $\begin{array}{l}2.5 \\
5.7 \\
6.0\end{array}$ & $\begin{array}{l}57.2 \\
67.2 \\
65.0\end{array}$ & $\begin{array}{l}295.3 \\
305.5 \\
256.9\end{array}$ & $\begin{array}{l}3.4 \\
5.0 \\
5.8\end{array}$ & .220 & $\begin{array}{r}1.47 \\
1.07 \\
.97\end{array}$ & $\begin{array}{l}24.9 \\
11.7 \\
10.8\end{array}$ \\
\hline & $190 / 120$ & $\begin{array}{r}11.6 \\
5.8 \\
4.2\end{array}$ & $\begin{array}{l}66.3 \\
65.0 \\
64.1\end{array}$ & $\begin{array}{l}176.0 \\
165.9 \\
160.2\end{array}$ & $\begin{array}{l}4.0 \\
3.3 \\
3.6\end{array}$ & .389 & $\begin{array}{l}.34 \\
.58 \\
.87\end{array}$ & $\begin{array}{r}5.7 \\
11.3 \\
15.4\end{array}$ \\
\hline & $228 / 120$ & $\begin{array}{r}9.7 \\
12.7 \\
6.7\end{array}$ & $\begin{array}{l}67.4 \\
60.6 \\
58.0\end{array}$ & $\begin{array}{l}345.4 \\
271.8 \\
298.5\end{array}$ & $\begin{array}{l}4.5 \\
3.6\end{array}$ & .204 & $\begin{array}{l}.31 \\
.54\end{array}$ & $\begin{array}{l}5.0 \\
7.7\end{array}$ \\
\hline & $210 / 126$ & $\begin{array}{l}6.8 \\
6.1\end{array}$ & $\begin{array}{l}61.9 \\
61.3\end{array}$ & $\begin{array}{l}291.7 \\
266.6\end{array}$ & $\begin{array}{l}3.4 \\
4.1\end{array}$ & .213 & $\begin{array}{l}.52 \\
.69\end{array}$ & $\begin{array}{r}9.7 \\
10.1\end{array}$ \\
\hline \multirow[t]{2}{*}{ W. G. } & $220 / 134$ & $\begin{array}{l}9.4 \\
6.7 \\
5.4\end{array}$ & $\begin{array}{l}92.5 \\
94.5 \\
92.8\end{array}$ & $\begin{array}{l}337.1 \\
316.1 \\
335.6\end{array}$ & $\begin{array}{l}6.5 \\
6.0 \\
7.4\end{array}$ & .284 & $\begin{array}{r}.69 \\
.90 \\
1.23\end{array}$ & $\begin{array}{r}9.8 \\
14.3 \\
17.1\end{array}$ \\
\hline & $180 / 110$ & $\begin{array}{l}4.6 \\
3.3\end{array}$ & $\begin{array}{l}98.0 \\
85.0\end{array}$ & $\begin{array}{l}328.0 \\
384.0\end{array}$ & $\begin{array}{l}2.8 \\
2.3\end{array}$ & .299 & $\begin{array}{l}.59 \\
.70\end{array}$ & $\begin{array}{l}21.1 \\
27.0\end{array}$ \\
\hline \multirow[t]{3}{*}{ C. S. } & $184 / 132$ & $\begin{array}{l}4.6 \\
6.0\end{array}$ & $\begin{array}{r}77.0 \\
107.2\end{array}$ & $\begin{array}{l}514.4 \\
603.9\end{array}$ & $\begin{array}{l}3.0 \\
3.9\end{array}$ & .187 & $\begin{array}{l}.69 \\
.71\end{array}$ & $\begin{array}{l}16.9 \\
18.1\end{array}$ \\
\hline & $158 / 112$ & $\begin{array}{l}4.7 \\
2.9\end{array}$ & $\begin{array}{l}63.7 \\
73.8\end{array}$ & $\begin{array}{l}420.0 \\
422.2\end{array}$ & $\begin{array}{l}3.9 \\
5.7\end{array}$ & .149 & $\begin{array}{l}1.10 \\
2.10\end{array}$ & $\begin{array}{l}12.1 \\
26.7\end{array}$ \\
\hline & $184 / 120$ & $\begin{array}{l}3.4 \\
2.9 \\
4.0\end{array}$ & $\begin{array}{r}66.2 \\
76.6 \\
103.0\end{array}$ & $\begin{array}{l}300.0 \\
328.0 \\
357.0\end{array}$ & $\begin{array}{l}3.0 \\
3.1 \\
4.0\end{array}$ & .249 & $\begin{array}{r}.86 \\
1.09 \\
.99\end{array}$ & $\begin{array}{l}18.8 \\
26.8 \\
25.6\end{array}$ \\
\hline M. S. & $144 / 86$ & $\begin{array}{l}6.7 \\
7.1 \\
7.0\end{array}$ & $\begin{array}{l}135.6 \\
133.2 \\
134.0\end{array}$ & $\begin{array}{l}795.6 \\
729.9 \\
679.6\end{array}$ & $\begin{array}{l}4.5 \\
5.2 \\
4.9\end{array}$ & .183 & $\begin{array}{l}.68 \\
.73 \\
.69\end{array}$ & $\begin{array}{l}20.2 \\
18.7 \\
19.2\end{array}$ \\
\hline L. McG. & $240 / 140$ & $\begin{array}{l}7.1 \\
8.0\end{array}$ & $\begin{array}{l}72.4 \\
66.2\end{array}$ & $\begin{array}{l}328.0 \\
246.6\end{array}$ & $\begin{array}{l}6.6 \\
6.4\end{array}$ & .255 & $\begin{array}{l}.93 \\
.80\end{array}$ & $\begin{array}{r}10.2 \\
8.3\end{array}$ \\
\hline E. L. & $200 / 138$ & $\begin{array}{l}4.9 \\
1.8\end{array}$ & $\begin{array}{l}75.1 \\
76.8\end{array}$ & & $\begin{array}{l}4.1 \\
3.7\end{array}$ & & 2.08 & $\begin{array}{l}15.2 \\
42.7\end{array}$ \\
\hline E. A. & $175 / 105$ & $\begin{array}{l}1.4 \\
2.6 \\
2.8\end{array}$ & $\begin{array}{l}49.9 \\
67.4 \\
94.7\end{array}$ & $\begin{array}{l}306.0 \\
405.0 \\
548.0\end{array}$ & $\begin{array}{l}1.8 \\
2.6 \\
3.5\end{array}$ & .169 & $\begin{array}{l}1.24 \\
1.00 \\
1.22\end{array}$ & $\begin{array}{l}35.1 \\
26.4 \\
33.6\end{array}$ \\
\hline S. D. & $202 / 112$ & $\begin{array}{l}5.1 \\
9.1 \\
8.5\end{array}$ & $\begin{array}{l}31.0 \\
43.3 \\
46.5\end{array}$ & $\begin{array}{l}125.0 \\
151.0 \\
152.0\end{array}$ & $\begin{array}{l}6.0 \\
6.9 \\
6.5\end{array}$ & .282 & $\begin{array}{l}.90 \\
.77 \\
.77\end{array}$ & $\begin{array}{l}6.0 \\
4.8 \\
5.5\end{array}$ \\
\hline V. D. & $160 / 110$ & $\begin{array}{l}3.5 \\
3.3 \\
4.2\end{array}$ & $\begin{array}{r}88.7 \\
101.0 \\
96.5\end{array}$ & $\begin{array}{l}459.0 \\
460.0 \\
458.0\end{array}$ & $\begin{array}{l}4.9 \\
5.1 \\
5.2\end{array}$ & .208 & $\begin{array}{l}1.37 \\
1.59 \\
1.29\end{array}$ & $\begin{array}{l}25.4 \\
31.8 \\
23.0\end{array}$ \\
\hline
\end{tabular}


REABSORPTION OF CHLORIDE IN HYPERTENSION

TABLE II

Data obtained from a single patient with essential arterial hypertension

\begin{tabular}{|c|c|c|c|c|c|c|c|c|}
\hline & B.P. & ml. per min. & $\mathrm{C}_{\text {In. }}$ & $\mathrm{C}_{\text {Diod. }}$ & $\mathrm{C}_{\text {Chlor. }}$ & FF & U/P Chlor & U/P In. \\
\hline \multirow[t]{7}{*}{ C. V. } & $200 / 105$ & $\begin{array}{l}2.0 \\
2.0 \\
2.1 \\
1.0\end{array}$ & $\begin{array}{l}68.9 \\
61.2 \\
74.3 \\
45.3\end{array}$ & $\begin{array}{l}253.0 \\
205.0 \\
233.0 \\
139.0\end{array}$ & $\begin{array}{l}3.0 \\
2.3 \\
2.4 \\
1.4\end{array}$ & .301 & $\begin{array}{l}1.52 \\
1.16 \\
1.16 \\
1.39\end{array}$ & $\begin{array}{l}35.0 \\
31.4 \\
35.5 \\
47.0\end{array}$ \\
\hline & $210 / 110$ & $\begin{array}{l}2.0 \\
1.7 \\
1.6 \\
1.4\end{array}$ & $\begin{array}{l}60.4 \\
52.0 \\
55.6 \\
46.7\end{array}$ & $\begin{array}{l}261.0 \\
242.5 \\
246.5 \\
234.0\end{array}$ & $\begin{array}{l}2.5 \\
2.2 \\
2.2 \\
1.9\end{array}$ & .202 & $\begin{array}{l}1.25 \\
1.27 \\
1.42 \\
1.38\end{array}$ & $\begin{array}{l}29.2 \\
30.4 \\
35.5 \\
34.1\end{array}$ \\
\hline & $208 / 108$ & $\begin{array}{l}3.8 \\
2.5 \\
1.9 \\
2.2\end{array}$ & $\begin{array}{l}58.0 \\
53.0 \\
41.6 \\
49.0\end{array}$ & $\begin{array}{l}220.0 \\
218.5 \\
225.2 \\
228.0\end{array}$ & $\begin{array}{l}3.9 \\
3.5 \\
3.3 \\
2.9\end{array}$ & .226 & $\begin{array}{l}1.05 \\
1.43 \\
1.75 \\
1.32\end{array}$ & $\begin{array}{l}15.3 \\
21.4 \\
22.1 \\
22.3\end{array}$ \\
\hline & $228 / 125$ & $\begin{array}{l}4.3 \\
2.8 \\
4.1 \\
2.7\end{array}$ & $\begin{array}{l}52.0 \\
57.2 \\
64.8 \\
62.6\end{array}$ & $\begin{array}{l}256.0 \\
247.5 \\
271.7 \\
247.8\end{array}$ & $\begin{array}{l}3.5 \\
3.5 \\
4.2 \\
4.1\end{array}$ & .231 & $\begin{array}{r}.80 \\
1.27 \\
1.06 \\
1.50\end{array}$ & $\begin{array}{l}12.0 \\
20.5 \\
16.3 \\
23.1\end{array}$ \\
\hline & $228 / 120$ & $\begin{array}{r}9.7 \\
12.9 \\
9.8\end{array}$ & $\begin{array}{l}67.4 \\
60.6 \\
58.0\end{array}$ & $\begin{array}{l}345.4 \\
271.8 \\
298.5\end{array}$ & $\begin{array}{l}4.5 \\
3.6\end{array}$ & .204 & $\begin{array}{l}.31 \\
.54\end{array}$ & $\begin{array}{l}5.0 \\
7.7\end{array}$ \\
\hline & $210 / 140$ & $\begin{array}{l}2.3 \\
5.7 \\
6.0\end{array}$ & $\begin{array}{l}57.2 \\
67.2 \\
65.0\end{array}$ & $\begin{array}{l}295.3 \\
305.5 \\
256.9\end{array}$ & $\begin{array}{l}3.4 \\
5.0 \\
5.8\end{array}$ & .220 & $\begin{array}{l}1.47 \\
1.07 \\
0.97\end{array}$ & $\begin{array}{l}24.9 \\
11.7 \\
10.8\end{array}$ \\
\hline & $190 / 120$ & $\begin{array}{r}11.6 \\
5.8 \\
4.2\end{array}$ & $\begin{array}{l}66.3 \\
65.0 \\
64.1\end{array}$ & $\begin{array}{l}176.0 \\
165.9 \\
160.2\end{array}$ & $\begin{array}{l}4.0 \\
3.3 \\
3.6\end{array}$ & .389 & $\begin{array}{l}.34 \\
.58 \\
.87\end{array}$ & $\begin{array}{r}5.7 \\
11.3 \\
15.4\end{array}$ \\
\hline
\end{tabular}

that group than in the control (Tables III and IV). Although a strict correlation is not found between the chloride clearance and the urine output, the higher outputs are more apt to show high clearances. In the normals, however, the output volume has clearly no relation to the clearance of chloride. Converting to ratios, Figure 2 shows a different regression line with no overlapping, in the case of the hypertensive patient. Calculation of the regression line of this curve shows a positive intercept on the chloride scale, indicating that in this situation a constant proportion no longer exists, and that at $\mathrm{U} / \mathrm{P}$ inulin equals 1 , chloride is not being completely reabsorbed, but is passing out in the urine in concentration roughly equivalent to $1 / 2$ of plasma concentration. In view of the fact that the hypertensive data constitute not so much an absolute pattern as a derangement in varying degrees of a pattern, the definition and extrapolation of a regression line is of questionable value. For this reason, the statistical treatment of the hypertensive data in Figure 1 has been omitted, and the discussion is based rather on the observation that at all $U / P$ inulin ratios, the hypertensive patients reabsorb less chloride than do the normal subjects. Thus, not only do the tubules fail to reabsorb water, but, per unit of water reabsorbed, they demonstrate a specific failure to reabsorb chloride, with the result that at all dilutions the hyposthenuric output contains several times more chloride than normal.

The interpretation of these findings with respect to disposal of chloride by the kidney in hypertension is highly problematical. If the chloride clearance (Tables I and II) tends to vary with the urine volume, and the normal chloride economy gives evidence of impairment with resulting seepage of chloride in the urine, a chronic condition of relative chloride want might well be suspected. The scope of the present study does not permit more than conjecture as to the reasons for the reduced reabsorption which might be on a basis of adrenal cortical insufficiency, excess pitocin, or functional impairment of the proximal tubules. Whatever be the true explanation, such a modification of behavior toward chloride appears to be a specific 
TABLE III

Data obtained from a group of normal subjects

\begin{tabular}{|c|c|c|c|c|c|c|c|c|}
\hline & B.P. & ml. per min. & $\mathrm{C}_{\text {In. }}$ & $\mathrm{C}_{\text {Diod. }}$ & $\mathrm{C}_{\text {Chlor. }}$ & FF & U/P Chlor. & U/P In. \\
\hline L. H. & & $\begin{array}{l}4.4 \\
4.3 \\
3.6\end{array}$ & $\begin{array}{r}109.0 \\
109.0 \\
94.7\end{array}$ & $\begin{array}{l}608 \\
573 \\
501\end{array}$ & $\begin{array}{l}2.0 \\
2.3 \\
2.3\end{array}$ & .185 & $\begin{array}{l}.45 \\
.52 \\
.63\end{array}$ & $\begin{array}{l}24.9 \\
25.6 \\
26.3\end{array}$ \\
\hline J. S. & & $\begin{array}{l}1.7 \\
1.2 \\
1.7\end{array}$ & $\begin{array}{r}104.0 \\
95.8 \\
105.0\end{array}$ & $\begin{array}{l}548 \\
510 \\
543\end{array}$ & $\begin{array}{l}1.1 \\
1.0 \\
1.1\end{array}$ & .189 & $\begin{array}{l}.69 \\
.83 \\
.64\end{array}$ & $\begin{array}{l}62.8 \\
80.5 \\
60.0\end{array}$ \\
\hline M. S. & & $\begin{array}{l}5.7 \\
2.5 \\
2.7\end{array}$ & $\begin{array}{l}72.2 \\
79.0 \\
72.2\end{array}$ & $\begin{array}{l}357 \\
398 \\
346\end{array}$ & $\begin{array}{l}1.6 \\
1.9 \\
1.9\end{array}$ & .201 & $\begin{array}{l}.28 \\
.77 \\
.72\end{array}$ & $\begin{array}{l}12.8 \\
31.6 \\
27.2\end{array}$ \\
\hline E. $H$. & & $\begin{array}{l}1.2 \\
1.1 \\
2.6\end{array}$ & $\begin{array}{l}85.0 \\
84.2 \\
78.6\end{array}$ & $\begin{array}{l}605 \\
549 \\
506\end{array}$ & $\begin{array}{l}1.3 \\
1.3 \\
1.1\end{array}$ & .149 & $\begin{array}{r}1.14 \\
1.22 \\
.44\end{array}$ & $\begin{array}{l}56.0 \\
76.5 \\
30.7\end{array}$ \\
\hline M. E. & & $\begin{array}{l}8.1 \\
3.3 \\
2.6\end{array}$ & $\begin{array}{l}121.0 \\
145.0 \\
124.0\end{array}$ & $\begin{array}{l}658 \\
638 \\
497\end{array}$ & $\begin{array}{l}1.7 \\
1.9 \\
1.7\end{array}$ & .221 & $\begin{array}{l}.17 \\
.56 \\
.74\end{array}$ & $\begin{array}{l}14.8 \\
43.6 \\
52.3\end{array}$ \\
\hline I. F. & & $\begin{array}{r}3.9 \\
3.8 \\
.5\end{array}$ & $\begin{array}{l}76.0 \\
74.3 \\
76.3\end{array}$ & $\begin{array}{l}446 \\
361 \\
447\end{array}$ & $\begin{array}{l}2.3 \\
1.8 \\
1.4\end{array}$ & .180 & $\begin{array}{r}.59 \\
.47 \\
2.84\end{array}$ & $\begin{array}{r}19.6 \\
19.6 \\
124.0\end{array}$ \\
\hline M. M. & & $\begin{array}{r}6.9 \\
2.8 \\
.8\end{array}$ & $\begin{array}{l}93.6 \\
68.9 \\
80.8\end{array}$ & $\begin{array}{l}463 \\
338 \\
504\end{array}$ & $\begin{array}{l}1.1 \\
1.3 \\
1.6\end{array}$ & .187 & $\begin{array}{r}.16 \\
.42 \\
2.06\end{array}$ & $\begin{array}{r}13.6 \\
24.4 \\
106.0\end{array}$ \\
\hline C. $\mathrm{H}$. & & $\begin{array}{l}1.6 \\
2.7\end{array}$ & $\begin{array}{l}118.0 \\
136.0\end{array}$ & $\begin{array}{l}508 \\
690\end{array}$ & $\begin{array}{l}1.8 \\
2.3\end{array}$ & .211 & $\begin{array}{l}.91 \\
.87\end{array}$ & $\begin{array}{l}52.7 \\
50.4\end{array}$ \\
\hline V. M. & & $\begin{array}{l}2.3 \\
1.5 \\
1.2\end{array}$ & $\begin{array}{r}82.7 \\
96.4 \\
112.0\end{array}$ & $\begin{array}{l}374 \\
421 \\
427\end{array}$ & $\begin{array}{l}1.5 \\
1.6 \\
1.7\end{array}$ & .238 & $\begin{array}{l}.65 \\
1.08 \\
1.51\end{array}$ & $\begin{array}{l}35.0 \\
66.0 \\
98.2\end{array}$ \\
\hline M. D. & & $\begin{array}{l}1.2 \\
1.8\end{array}$ & $\begin{array}{l}134.6 \\
194.2\end{array}$ & $\begin{array}{r}715 \\
1104\end{array}$ & $\begin{array}{l}2.2 \\
3.6\end{array}$ & .181 & $\begin{array}{l}1.87 \\
2.00\end{array}$ & $\begin{array}{l}111.2 \\
108.5\end{array}$ \\
\hline T. B. & & $\begin{array}{l}1.9 \\
1.8 \\
2.1\end{array}$ & $\begin{array}{l}83.0 \\
85.2 \\
92.7\end{array}$ & $\begin{array}{l}452 \\
483 \\
492\end{array}$ & $\begin{array}{l}2.1 \\
2.2 \\
2.3\end{array}$ & .183 & $\begin{array}{l}1.07 \\
1.21 \\
1.07\end{array}$ & $\begin{array}{l}43.3 \\
47.5 \\
43.7\end{array}$ \\
\hline D. R. & & $\begin{array}{l}8.6 \\
7.7 \\
3.9\end{array}$ & $\begin{array}{l}76.7 \\
83.8 \\
69.0\end{array}$ & $\begin{array}{l}430 \\
460 \\
347\end{array}$ & $\begin{array}{l}2.7 \\
2.5 \\
2.3\end{array}$ & .186 & $\begin{array}{l}.31 \\
.33 \\
.63\end{array}$ & $\begin{array}{r}8.9 \\
14.7 \\
18.6\end{array}$ \\
\hline
\end{tabular}

characteristic inherent in the tubules, or in which the tubular epithelium acts as the agent.

\section{SUMMARY AND CONCLUSIONS}

Studies of the filtration rate, renal blood flow and chloride excretion were performed by means of concomitant clearance tests of inulin, diodrast and chloride upon: (a) a group of normal individuals and $(b)$ a group of patients with "essential hypertension." By the same method protracted studies were done of: $(a)$ a single individual without vascular or renal disease and $(b)$ a patient of corresponding age and sex with well established hypertension.
Tabulation of chloride clearance and urine flow in these groups showed a fixed range of chloride clearance independent of the urine flow in the normal individuals. In the hypertensive patients the chloride clearance tended to vary directly with the urine flow.

Plotting of $U / P$ chloride against $U / P$ inulin in the normal cases resulted in a straight line relationship of constant proportion, which in the group study, as in the individual, dropped below $U / P$ chloride values of 1 and approached zero. It was, therefore, demonstrated that under conditions of extreme diuresis, the tubular epithelium actively retracted the chloride from the filtrate, with the 
REABSORPTION OF CHLORIDE IN HYPERTENSION

TABLE IV

Data obtained from a single normal subject

\begin{tabular}{|c|c|c|c|c|c|c|c|c|}
\hline & B.P. & ml. per min. & $\mathrm{C}_{\text {In. }}$ & $\mathrm{C}_{\text {Diod. }}$ & $\mathrm{C}_{\text {Chlor. }}$ & FF & U/P Chlor. & U/P In. \\
\hline \multirow[t]{7}{*}{ J. P. } & & $\begin{array}{l}2.9 \\
1.7 \\
2.3 \\
0.8\end{array}$ & $\begin{array}{r}106.0 \\
85.0 \\
85.5 \\
85.2\end{array}$ & $\begin{array}{l}596 \\
400 \\
418 \\
400\end{array}$ & $\begin{array}{l}1.9 \\
1.3 \\
1.2 \\
1.1\end{array}$ & 199 & $\begin{array}{r}.7 \\
.8 \\
.5 \\
1.3\end{array}$ & $\begin{array}{r}36.4 \\
48.4 \\
37.8 \\
103.0\end{array}$ \\
\hline & & $\begin{array}{l}3.3 \\
2.2 \\
4.1 \\
3.0\end{array}$ & $\begin{array}{l}74.5 \\
81.0 \\
78.0 \\
78.9\end{array}$ & $\begin{array}{l}412 \\
420 \\
403 \\
407\end{array}$ & $\begin{array}{l}1.2 \\
1.3 \\
1.3 \\
1.3\end{array}$ & 190 & $\begin{array}{l}.4 \\
.6 \\
.3 \\
.3\end{array}$ & $\begin{array}{l}22.3 \\
36.9 \\
18.9 \\
26.1\end{array}$ \\
\hline & & $\begin{array}{l}0.7 \\
0.7 \\
0.3 \\
1.4\end{array}$ & $\begin{array}{l}86.5 \\
77.9 \\
68.2 \\
75.5\end{array}$ & & $\begin{array}{l}1.4 \\
1.3 \\
1.1 \\
1.4\end{array}$ & , & $\begin{array}{l}2.1 \\
1.7 \\
3.9 \\
1.0\end{array}$ & $\begin{array}{r}130.0 \\
105.0 \\
253.0 \\
53.0\end{array}$ \\
\hline & & $\begin{array}{l}1.2 \\
1.0 \\
0.7 \\
2.4\end{array}$ & $\begin{array}{l}68.2 \\
78.4 \\
76.6 \\
91.5\end{array}$ & $\begin{array}{l}366 \\
425 \\
423 \\
534\end{array}$ & $\begin{array}{l}1.2 \\
1.2 \\
1.3 \\
1.5\end{array}$ & .180 & $\begin{array}{r}.9 \\
1.3 \\
1.9 \\
.6\end{array}$ & $\begin{array}{r}56.1 \\
80.5 \\
115.0 \\
38.3\end{array}$ \\
\hline & & $\begin{array}{l}3.6 \\
0.8 \\
0.9 \\
0.9\end{array}$ & $\begin{array}{l}82.1 \\
78.6 \\
82.5 \\
69.5\end{array}$ & $\begin{array}{l}464 \\
418 \\
430 \\
360\end{array}$ & $\begin{array}{l}1.9 \\
1.1 \\
1.2 \\
1.1\end{array}$ & .187 & $\begin{array}{r}.5 \\
1.5 \\
1.4 \\
1.2\end{array}$ & $\begin{array}{r}22.8 \\
104.0 \\
95.5 \\
72.5\end{array}$ \\
\hline & & $\begin{array}{l}1.4 \\
4.1 \\
3.1\end{array}$ & $\begin{array}{l}51.6 \\
75.4 \\
86.6\end{array}$ & $\begin{array}{l}276 \\
440 \\
516\end{array}$ & $\begin{array}{l}0.7 \\
0.9 \\
1.0\end{array}$ & .173 & $\begin{array}{l}.5 \\
.2 \\
.3\end{array}$ & $\begin{array}{l}35.5 \\
18.6 \\
27.6\end{array}$ \\
\hline & & $\begin{array}{l}1.5 \\
1.0 \\
0.6 \\
0.7\end{array}$ & $\begin{array}{l}79.4 \\
87.6 \\
91.5 \\
92.4\end{array}$ & $\begin{array}{l}395 \\
378 \\
386 \\
445\end{array}$ & $\begin{array}{l}0.5 \\
0.5 \\
0.5 \\
0.6\end{array}$ & .218 & $\begin{array}{l}.3 \\
.5 \\
.9 \\
.9\end{array}$ & $\begin{array}{r}52.5 \\
84.7 \\
146.0 \\
131.0\end{array}$ \\
\hline
\end{tabular}

theoretical end-result that if no water whatever were reabsorbed in the tubules, all chloride would be reabsorbed, and the urine would be a chloridefree filtrate unmodified with respect to inulin. In order to explore the application of this method of analysis, phosphate values on the same case were similarly calculated and graphed. Phosphate was found to behave like a non-threshold substance, the $U / P$ ratio of which declined with the $U / P$ inulin to a theoretical value of 1 .

The $U / P$ chloride in both group and individual hypertension studies was higher at all $U / P$ inulin ratios than the normal curve. Such an alteration in behavior toward chloride represents an impairment of the normal reabsorption mechanism.

\section{BIBLIOGRAPHY}

1. Rehberg, P. B., Studies on kidney function; excretion of urea and chlorine analysed according to modified filtration-reabsorption theory. Biochem. J., 1926, 20, 461.

2. Dillon, T. W. T., Diuresis problem. The Irish J. Med. Sci., pp. 534 to 547, Sept. 1943.
3. Hare, R. S., Hare, K., and Phillips, D. M., Renal excretion of chloride by normal and by diabetes insipidus dog. Am. J. Physiol., 1943, 140, 334.

4. Shannon, J. A., Control of renal excretion of water; rate of liberation of posterior pituitary antidiuretic hormone in dog. J. Exper. Med., 1942, 76, 387.

5. Wolf, A. V., Relative retention of infused chloride, urea, and water. Am. J. Physiol., 1943, 138, 191.

6. Pitts, R. F., The renal regulation of acid base balance with special reference to the mechanism for acidifying the urine. Science, 1945, 102, 49.

7. Farnsworth, E. B., and Barker, M. H., Tubular resorption of chloride in hypertension and in normal individuals. Proc. Soc. Exper. Biol. and Med., 1943, $52,74$.

8. Farnsworth, E. B., and Barker, M. H., Tubular resorption of chloride in essential arterial hypertension : intensive study of one case. Proc. Soc. Exper. Biol. and Med., 1943, 53, 160.

9. Sendroy, J., Micro determination of chloride in biological fluids, with solid silver iodate. J. Biol. Chem., 1937, 120, 335.

10. Corcoran, A. C., and Page, I. H., Applications of diphenylamine in determination of levulose in biological media; determination of inulin, determination of levulose in small amounts of blood. J. Biol. Chem., 1939, 127, 601. 